Dostoevskii's Forgotten Children: Lost Babies and Baby Loss in The Adolescent Author(s): Muireann Maguire

Source: The Slavonic and East European Review, January 2021, Vol. 99, No. 1 (January 2021), pp. 98-123

Published by: the Modern Humanities Research Association and University College London, School of Slavonic and East European Studies

Stable URL: https://www.jstor.org/stable/10.5699/slaveasteurorev2.99.1.0098

JSTOR is a not-for-profit service that helps scholars, researchers, and students discover, use, and build upon a wide range of content in a trusted digital archive. We use information technology and tools to increase productivity and facilitate new forms of scholarship. For more information about JSTOR, please contact support@jstor.org.

Your use of the JSTOR archive indicates your acceptance of the Terms \& Conditions of Use, available at https://about.jstor.org/terms 


\title{
Dostoevskii's Forgotten Children: Lost Babies and Baby Loss in The Adolescent
}

\author{
MUIREANN MAGUIRE
}

A baby vanishes

A baby disappears from the drafts of Dostoevskii's Prestuplenie i nakazanie (Crime and Punishment, 1866). He was not intended to live: delivered by Caesarean section at only six months' gestation from his mother's murdered body, he never stood a chance. His mother was Lizaveta, the pawnbroker's sister; his father, a certain Bakavin (renamed Zosimov in the final draft of the novel). This tiny tragedy is conveyed to the novel's hero Raskol'nikov as gossip by Nastas'ia, who even in Dostoevskii's early notes for Crime and Punishment is already identified as both Lizaveta's friend and the maidservant of Raskol'nikov's landlady. ${ }^{1}$ But in the published version of the novel, the baby has vanished. The subplot of Lizaveta's pregnancy has followed her son into non-existence: Dostoevskii merely hints that Lizaveta may have been with child at the time of her murder, via a minor character's remark that she is 'forever pregnant'. ${ }^{2}$ Thus, the narrative fact of the dead infant is expunged from the novel's final variant; only a flimsy hypothesis of its potential existence lingers in the text. Lost infants like this

\section{Muireann Maguire is Senior Lecturer in Russian at the University of Exeter.}

I would like to warmly thank the editors, Sarah Young and Bilal Siddiqi, for organizing the 2017 conference at UCL SSEES on 'Revolutionary Dostoevsky' at which the earliest draft of this article was first presented; I am grateful to the anonymous peer reviewers for their incisive and helpful comments on the next version. I dedicate this article in respectful memory of the late Diane Oenning Thompson (University of Cambridge), a wise and much-missed scholar, who inspired and supported my earliest readings on Dostoevskii. It was a privilege to revisit her work during my research for this paper.

1 “'But don't you know? They performed a Caesarean on her [potroshili]. She was six months' pregnant. A boy, born dead" [said Nastasya]', in Fyodor Dostoevsky, The Notebooks for Crime and Punishment, ed. and trans. Edward Wasiolek, Chicago, IL and London, 1967, p. 96; F. M. Dostoevskii, Prestuplenie i nakazanie: rukopisnye redaktsii, in Polnoe sobranie sochinenii (hereafter, PSS), 30 vols, Leningrad, 1972-90, 7, p. 71.

2 Fyodor Dostoevsky, Crime and Punishment, trans. Oliver Ready, London, 2014, p. 79. 
one are surprisingly abundant in Dostoevskii's fiction. Some simply lapse from the narrative, like the orphaned baby sheltered by Andrei Petrovich Versilov in Podrostok (The Adolescent, 1875), whose afterstory is never told; others perish within the narrative frame, like the two infant girls (both called Arina) and the child miscarried by Versilov's daughter Liza in the same novel. Still others, like Lizaveta's unborn son described above in Crime and Punishment (and indeed, her adult daughter Siasia), appear only in early drafts, to be edited out of the final printed version. Are these babies really lost, or do they return on a thematic level? Should we interpret Dostoevskii's lack of closure regarding infant characters as accidental, if recurrent, omissions, or as metatextual warnings about the vanity of human aspiration and, by analogy, about the unreliability of narrative? And how do we reconcile the apparently nihilistic message of infant mortality in novels like Besy (Demons, 1872) and Brat'ia Karamazovy (Brothers Karamazov, 1880) with Dostoevskii's Christian faith and his outspoken love of children?

To answer these questions, this article performs a new reading of The Adolescent - a novel which is itself a kind of lost literary offspring, overshadowed and overlapped by both its immediate predecessor, Demons, and its successor, Brothers Karamazov. The Adolescent was written to critique a disturbing new phenomenon in mid-nineteenth-century Russian society. As old patriarchal ties of lineage and morality lost their certainty, new non-familial kinships between friends and lovers - so-called 'accidental families' ('semeistva sluchainye'), ${ }^{3}$ to use Dostoevskii's phrase from this novel - replaced them. Kate Holland writes that '[o]f all Dostoevskii's works of the period, The Adolescent deals most directly with the experience of social transition in the postreform era and its effects on novelistic representation.' ${ }^{4}$ Perhaps because it catalogues the successes and failures (mostly, the failures) of these 'accidental' relationships, its myriad subplots include more orphaned and doomed babies than any other Dostoevskii novel. Dostoevskii's apparent carelessness with fictional babies here and elsewhere is part of his well-known tendency to leave unfinished plots and create narrative lacunae. My re-reading of the lost infants of The Adolescent, in conjunction with similar stories from other major novels, suggests that discarded subplots like these form an important part of Dostoevskii's aesthetic repertoire. His aporetic, or unfinalized, narratives

3 F. M. Dostoevskii, Podrostok, PSS, 13, p. 455.

4 Kate Holland, The Novel in the Age of Disintegration: Dostoevsky and the Problem of Genre in the 1870s, Evanston, IL, 2013, p. 20. 
(most poignantly including stories of infant mortality) constitute an intentional strategy of refusing his reader happy endings. His fiction deliberately resists generational continuity, family harmony and tidy narratives with a specific point in mind. Thus The Adolescent's lost babies may help us to untangle some of the most paradoxical, yet essential, aspects of Dostoevskii's philosophical message.

Reading Dostoevskii's plot 'flaws', or divergences from conventional plotlines, as intentional authorial strategies has gained traction in recent scholarship. Anna Berman suggests that Dostoevskian family plots invariably resist the re-assertion of legitimacy and order, just as they resist future-oriented narrative, because moral conduct in the present is more important than the assurance offered by blood ancestors or genetic heirs. ${ }^{6}$ Yuri Corrigan has made a case for The Adolescent as an 'unorthodox' Bildungsroman because it focuses on 'the ruin of the self' rather than its construction. This critical shift towards interpreting lacunae and untidy plots as a deliberate narrative ploy (rather than critiquing the author's stylistic control) is founded upon many previous studies of chaotic families, futility and forgetfulness in Dostoevskii's fiction. ${ }^{8}$ By linking the contentions of Holquist and others to the resurrectionist doctrine of Nikolai Fedorov, with which Dostoevskii expressed sympathy, we can better understand why characters' attempts to become parents, whether genetic or adoptive - for example, in Demons and The Adolescent so frequently and consistently fail. ${ }^{9}$ And by adapting Carol Apollonio's 'apophatic' reading of Demons, we can begin to read these novels' ironic

5 See, for example, Greta Matzner-Gore's Dostoevsky and the Ethics of Narrative Form: Suspense, Closure, Minor Characters, Evanston, IL, 2020, on the centrality of conflict, discord and unfinalized plots in Dostoevskian aesthetics.

6 I am thankful to the editors and to Anna Berman for letting me see a proof version of her chapter, 'Dostoevskii and the (Missing) Marriage Plot', in Katherine Bowers and Kate Holland (eds) Dostoevsky at 20o: The Novel in Modernity, Toronto, ON, forthcoming (2021).

7 See Yuri Corrigan, Dostoevsky and the Riddle of the Self, Evanston, IL, 2017, pp. 104-19 (p. 105).

8 In her study of amnesia in Brothers Karamazov, Diane Oenning Thompson was among the first to contend that apparently accidental narrative lacunae (such as forgotten characters) may express an intentional strategy by Dostoevskii. See her The Brothers Karamazov and the Poetics of Memory, Cambridge, 2009, esp. pp. 158-78. Noting that generational difference is often expressed in Dostoevskii's novels by almost tribal opposition between sons and fathers (including adopted sons and surrogate fathers), Michael Holquist asks, 'How can sons become fathers?' Brothers Karamazov, he suggests, is essentially concerned with proving 'that a son can become a father'. See Holquist, Dostoevsky and the Novel, Princeton, NJ, 1977, pp. 174-75.

9 Ibid. 
reversals of fortune, most tragically expressed through the death of young children, as messages of hope, however paradoxical they appear. ${ }^{10}$

Dostoevskii loved children, especially babies; he believed in the redemption of mankind through good works and faith in Christ; and yet his novels kill off unborn and newborn infants with almost perverse consistency. The apparent contradiction between the first and third statements is resolved by the second. Religious faith and the intrinsic sacrality of childhood were central to Dostoevskii's perception of the world: and yet his plotlines that mistreat or kill off children were no more intended to deny the certainty of salvation than, for example, Ivan Karamazov's parable of Christ at the mercy of the Grand Inquisitor was meant to deny faith. Life lived without divine inspiration was, for Dostoevskii as for some of his characters, comparable to death; the narrator of Zapiski iz podpol'ia (Notes from Underground, 1864), for example, in his concluding rant, condemns his own generation: 'We are born dead [mertvorozhdennye], and moreover we have long ceased to be the sons of living fathers. ${ }^{11}$

Birth into this kind of life-in-death could not represent hope or renewal, rather its opposite; and early death represented release rather than despair. Consider, in this context, Dostoevskii's choice of Jesus's words from John 12:24 as the epigraph to Brothers Karamazov: 'Except a corn of wheat fall into the ground and die, it abideth alone: but if it die, it bringeth forth much fruit.' The next line, not cited by Dostoevskii but well-known to his readers, was, 'He that loveth his life shall lose it; and he that hateth his life in this world shall keep it unto life eternal'. ${ }^{12}$ In Dostoevskii's symbolic universe, as in Jesus's preaching, values are flipped: death is happier than life, and the death of an infant is cause for rejoicing. In conventional, secular narratives, pregnancy and births encode renewal and redemption; they signal happy endings and extradiegetic continuation. For Dostoevskii, literary birth was a dead letter: the only true birth, or renewal, came from within, by the resurrection of the dead self into a persona capable of bearing spiritual fruit. This is why Dostoevskii's fictional infants can die without negating the sense of renewal offered by their brief existence. When Dostoevskii wrote about the deaths of babies, he was expressing his message of hope in the strongest symbolic language he knew; and the more perversely he violated traditional narrative teleology by (figuratively)

10 Carol Apollonio, Dostoevsky's Secrets: Reading Against The Grain, Evanston, IL, 2009, pp. 6-7.

11 Fyodor Dostoevsky, Notes from Underground and The Double, trans. Jessie Coulson, London, 1972, pp. 13-123 (p. 123); Dostoevskii, Zapiski iz podpol'ia, PSS, 5, pp. 99-179 (p. 179).

${ }_{12}$ Both citations are from the King James Bible. 
stifling an infant, or by refusing to finalize a plotline about pregnancy, the more forcefully he inscribed his demand for individual, spiritual rebirth in his readers' minds. Children represent innocence and renewal: babies, however, as the quintessential image of hope, naturally became Dostoevskii's principal symbol of the futility of change without spiritual transformation. The remainder of this article will read the subplots of baby loss in The Adolescent as vehicles for his paradoxical message of hope. First, however, I will summarize how Dostoevskii experienced the deaths of children in his own life and in his wider fiction. ${ }^{13}$

\section{Birth and loss in Dostoevskii}

Dostoevskii's love for and fascination with children is well documented, clearly demonstrated in his private life as well as his journalism and prose. ${ }^{14} \mathrm{He}$ was a responsible and affectionate uncle and stepfather, and a loving father; sadly, two of his own four children died in infancy. ${ }^{15}$ When his first child Sonia died of pneumonia at only three months old in Geneva in May 1868, his wife Anna Grigor'evna recalled that Dostoevskii 'sobbed and wept, like a woman; standing by the cold body of his darling, he covered her pale face and tiny hands with burning kisses. I have never seen such fierce despair since. Neither of us thought that we would overcome our grief' ${ }^{16}$ Tragically, ten years later his youngest son Alesha also died, aged three. Dostoevskii's and his wife's suffering at this double bereavement was almost certainly reflected in the characters of Alesha and of the various grieving mothers in Brothers Karamazov. ${ }^{17}$ No surprise, then, that Viacheslav Ivanov should flag up 'Dostoevskii's metaphysics of childhood' for special attention, commenting that ' $[\mathrm{t}]$ he child is the central

13 For a more detailed short survey of Dostoevskii's attitude to children, see Robin Feuer Miller, 'Children', in Deborah A. Martinsen and Olga Maiorova (eds), Dostoevsky in Context, Cambridge, 2016, pp. 139-47.

${ }^{14}$ In January 1876, he wrote: 'Even formerly I always used to observe children, but now I am especially observing them. Long ago I set myself the ideal of writing a novel about contemporaneous Russian children and, of course, about their present-day fathers.' F. M. Dostoievsky, The Diary of a Writer, ed. and trans. Boris Brasol, Salt Lake City, UT, 1985, pp. 159-6o; Dostoevskii, Dnevnik Pisatelia za 1876 god, PSS, 22, p. 7. William Woodin Rowe's Dostoevsky: Child and Man in His Works, New York, 1968, is a useful and inclusive analysis of the different representations and functions of children in all Dostoevskii's works.

15 On Dostoevskii's care for his brother's family and his stepson, see Joseph Frank, Dostoevsky: The Miraculous Years, Princeton, NJ, 1995, pp. 43 and 185-90, respectively.

${ }_{16}$ Anna Grigor'evna Dostoievskaia, Vospominaniia, Moscow, 1971, p. 178. My translation.

17 This is attested by A. G. Dostoievskaia in her memoirs (Vospominaniia, p. 322). See also Liza Knapp, 'Mothers and Sons in The Brothers Karamazov: Our Ladies of Skotoprigonevsk', in Robert Louis Jackson (ed.), A New Word on The Brothers Karamazov, Evanston, IL, 2004, pp. 31-52 (esp. pp. 34-36). 
point of [Dostoevskii's] doctrine concerning the world and concerning man'. Ivanov observes that, in Dostoevskii's novels, 'love of children, joy in them and close and direct contact with them' (not necessarily including parenthood, one notes) indicates 'a special state of grace'. ${ }^{18}$ At the same time, the vision of a grieving child symbolizes all possible wrongdoing: 'The world's unforgivable sin is the sin against children.' ${ }^{19}$

Paradoxically, then, Dostoevskii's narratives urge compassion for children by depicting its inverse: his plots typically revolve around acts of brutality and indifference towards the young. Almost every novel privileges the fictional persona of at least one abused, neglected, or dying child. Famously, Ivan Karamazov justifies his rejection of Christ on the grounds that no God who permits the abuse of children deserves our faith; the examples of maltreated children that Ivan gives are based on contemporary sources. ${ }^{20}$ Also in Brothers Karamazov, the death of a little boy called Il'iusha becomes an object lesson on empathy for his peers; a bereaved mother seeks comfort from Father Zosima; Dmitrii Karamazov dreams of a suffering baby; Dmitrii himself is briefly depicted as the neglected little 'Mitia', a 'motherless child' who is 'totally and completely abandoned' by his father. ${ }^{21}$ Nor was Dostoevskii's sympathy reserved for victims of physical or sexual abuse: Netochka Nezvanova, heroine of his eponymous (and unfinished) 1849 novel, endures almost intolerable emotional abuse from both her mother and her alcoholic stepfather. ${ }^{22}$ In his post-Siberian and overtly Dickensian novel, Unizhennye i oskorbliennye (The Insulted and the Injured, 1861), Dostoevskii connected three tragic, interlocking

18 Viacheslav Ivanov, Freedom and the Tragic Life: A Study in Dostoevsky, trans. Norman Cameron, New York, 1959, p. 95. Both Ivanov, in this passage, and Sarah Young in Dostoevsky's The Idiot and the Ethical Foundations of Narrative, London, 2004, pp. 91-93, cite the example of Prince Myshkin as an individual whose spiritual sincerity is enhanced by his childlike qualities.

19 Ivanov, Freedom and the Tragic Life, p. 95.

${ }^{20}$ See Joseph Frank, Dostoevsky: The Mantle of the Prophet 1871-1881, Princeton, NJ, 2002, p. 605.

${ }^{21}$ Thompson, Poetics of Memory, p. 161. There are too many other examples to list in full, but those given below emphasize the consistent centrality of this theme throughout Dostoevskii's career. Many of the characters in The Idiot have survived childhoods marred by neglect, disease, cruelty, or what we would now call sexual abuse: these include Ippolit, the Swiss girl befriended by Myshkin, Nastasi'a Filippovna and Prince Myshkin himself. In the chapter, 'U Tikhona' ('At Tikhon's'), excised from the first edition of Demons, Stavrogin confesses his abuse of an underage girl, which leads to her suicide; Crime and Punishment's Svidrigailov, a serial abuser of girls and women, hallucinates a depraved four-year-old lying in his bed.

${ }^{22}$ In his Heroine Abuse: Netochka Nezvanova and the Politics of Co-Dependency, Dekalb, IL, 2015, Thomas Gaiton Marullo argues that the emotional abuse of Netochka resumes in a different form when she is rescued from poverty (pp. 78-109). 
love stories through one neglected young girl: 'an unknown child [...] of twelve or thirteen, short, thin, and as pale as though she had just had some terrible illness [...]. Her whole dress might be described as rags and tatters. Her thick, black hair was matted and uncombed. ${ }^{23}$ This girl, Nellie, with her history of abandonment and (spurious) taint of illegitimacy, might be a precursor of The Adolescent's Arkadii (although unlike Arkadii, she dies before her fortunes improve). Her father, Valkovskii, a serial abandoner of children and women, could be a more consciously malignant forerunner of The Adolescent's Versilov.

Suffering children like these are usually read as evidence that Dostoevskii intended to model societal dysfunction through broken family units. According to Thomas Gaiton Marullo, 'it was precisely the breakdown of the family [as depicted in Dostoevskii's journalism and final novels] absentee fathers, unbalanced mothers, and neglected and abused children - that was sending Russia hurtling toward revolution and chaos. ${ }^{24}$ Fathers, especially failed or absent ones, have come in for the brunt of critical analysis ever since Freud pointed his psychoanalytic loupe in the direction of Dostoevskii's own relationship with his father. ${ }^{25}$ More recently, Anna Berman has contended that sibling or sibling-like relationships form between Dostoevskii's younger characters as experimental alternatives to the ineffectual or harmful parenting they have received. ${ }^{26}$ All such critiques presuppose that an alternative model of family life is possible, and that Dostoevskii was proposing some magic formula for personal and social regeneration, whether through the nuclear family or the kind of 'accidental family' created in The Adolescent.

${ }^{23}$ Fyodor Dostoevsky, The Insulted and Injured, trans. Constance Garnett, London, 1947, p. 48; Dostoevskii, Unizhennye i oskorblennye, in PSS, 3, pp. 169-442 (pp. 208-09). Nellie's character is clearly based on the tragic Little Nell in Dickens's The Old Curiosity Shop (1841).

${ }^{24}$ Marullo, Heroine Abuse, p. 157.

${ }^{25}$ For a psychobiographical analysis of Brothers Karamazov, see Sigmund Freud's 'Dostoevsky and Parricide' (1928), in D. Rancour-Laferrière, Russian Literature and Psychoanalysis, trans. V. Woolf, Amsterdam, 1989, pp. 41-58. On fathers in Dostoevskii, see also Holquist, Dostoevsky and the Novel, esp. 165-92; mothers escape relatively lightly, although Carol Apollonio's intriguing chapter, 'The Mothers Karamazov', in Reading Against the Grain (pp. 144-70) suggests that the mothers should share some responsibility for the demonic qualities of the Karamazov brothers.

${ }^{26}$ Anna Berman scrutinizes sibling bonds (biological or spiritual) between characters in Dostoevskii's novels, including The Idiot, Demons and The Adolescent, suggesting that '[w]hile broken parent-child relations provide the darkness Dostoevsky is so famous for depicting, among these failed verticals is a network of sibling bonds that offer a glimmer, and often a beacon, of light'. See Berman, Siblings in Tolstoy and Dostoevsky: The Path to Universal Brotherhood, Evanston, IL, 2015, p. 104. 
As I argued above, the symbolic value of birth as reconciliation and renewal is complicated by near-universal infant mortality in Dostoevskii's fiction. Rebirth as a metaphor for spiritual transformation is a ruling theme in three of the major novels, Crime and Punishment, Demons and Brothers Karamazov. ${ }^{27}$ The penultimate sentence of the former links a new creative venture (a new story) to a new phase in Raskol'nikov's emotional life:

But here a new story begins: the story of a man's gradual renewal and gradual rebirth, of his gradual crossing from one world to another, of his acquaintance with a new, as yet unknown reality. ${ }^{28}$

In both cases, as Robert L. Belknap notes, the language of rebirth is used by the implied author rather than by a character. ${ }^{29}$ Raskol'nikov actually dreams of a deadly epidemic; as a consequence, he feels genuine concern and compassion for the sick Sonia; which leads him by memory associations back to the Gospel story of the raising of Lazarus. Hence Raskol'nikov's transformation is achieved through imagery of resurrection rather than re-birth; the unconvincing rebirth metaphor is one reason why critics have remained divided over the ending of Crime and Punishment. The narrator's optimistic conclusion appears to whitewash the characters' much grimmer reality. ${ }^{30}$

The presence or absence of actual babies - here referring to both unborn children and infants - in the major novels is often overlooked entirely or examined only in the context of familial collapse or parental neglect. ${ }^{31}$ Yet the short lives of these babies are intrinsically significant,

${ }^{27}$ For more on the theme of rebirth in these novels, see Alexandra F. Rudicina, 'Crime and Myth: The Archetypal Pattern of Rebirth in Three Novels of Dostoevsky', PMLA, 87, 1972, 5, pp. 1065-74.

${ }^{28}$ Dostoevsky, Crime and Punishment, p. 658; Dostoevskii, Prestuplenie i nakazanie, in PSS, 6, p. 422.

${ }^{29}$ Robert L. Belknap, The Structure of The Brothers Karamazov, Evanston, IL, 1989, pp. 99-100.

${ }^{30}$ For a contemporary reading of the ending of Crime and Punishment as intentionally aporetic, see Kate Holland, 'The Clash of Deferral and Anticipation: Crime and Punishment's Epilogue and the Difficulties of Narrative Closure', Canadian Slavonic Papers, 62, 2020, 2, pp. 109-22. Here she suggests that the novel's 'open', unconvincing resolution is hermeneutically akin to the important plot lacunae (like Fedor Karamazov's murder) in later novels such as Demons and Brothers Karamazov.

${ }^{31}$ Two exceptions to this are Suzanne Fusso's 'Maidens in Childbirth: The Sistine Madonna in Dostoevskii's The Devils', Slavic Review, 54, 1995, 2, pp. 261-75, and Belknap's The Structure of The Brothers Karamazov. Fusso's article explores the symbolism of the birth and rapid death of Maria Shatova's infant in Demons; Belknap suggests that 
firstly because of the centrality of children to Dostoevskii's ethos, and secondly as universal symbols of failed inspiration. Just as birth itself is a laboured trope for artistic creativity, so the symbolism of miscarriage and infant death is often associated with failures of literary inspiration. ${ }^{32}$ I suggest that there are three categories of disappeared, or miscarried, infants in Dostoevskii's work. These groups correspond loosely to the three ways in which his plots diverge into formlessness: conceptual miscarriages, where an idea never passes the planning stage, like Lizaveta's dead son in the Crime and Punishment draft; structural miscarriages, where an infant apparently gets mislaid between subplots and thus drops out of the narrative; and symbolic deaths, where Dostoevskii explicitly kills off a child to convey an ideological message (most famously, the death of Maria Shatova's new-born child in Demons). ${ }^{33}$ The next part of this article will examine these categories, in turn, focusing primarily on their appearance in what may be the least-read and studied of Dostoevskii's mature works, The Adolescent. ${ }^{34}$

\section{'The Adolescent': Conceptual miscarriage}

The Adolescent can be seen as Dostoevskii's response to earlier and more conventionally structured 'family novels' which also explored the theme of changing generational dynamics, such as Tolstoi's Detstvo (Childhood, 1852) and Turgenev's Ottsy $i$ deti (Fathers and Sons, 1862). ${ }^{35}$ Less kind readers might imagine that The Adolescent was randomly generated from some original source code for Dostoevskian narrative. Redundant plotlines, melodramatic scandal scenes and duplicate characters abound: there is a charismatic father figure, the impoverished aristocrat Versilov, who reflects aspects of both Demons' Stavrogin and Crime and Punishment's

Dostoevskii exploits the trope of childbirth (normally the culmination of a chain of important events) with a minor character to subvert readers' expectations (pp. 86-87). Neither Belknap nor Fusso implies that the phenomenon of infant mortality in Dostoevskian narrative is susceptible to consistent interpretation.

32 Other Russian examples of this trope from the same period include Anton Chekhov's 'Imeniny' ('The Name-Day', 1894), in which a woman's miscarriage forces her to realize the superficiality of her marriage and her husband's social ambitions; or Tolstoi's Voskresen'e (Resurrection, 1899), where the obscure death of the baby born as a result of Nekhliudov's liaison with a young woman compounds the futility of their relationship.

33 See Muireann Maguire, 'Dostoevsky and the Politics of Parturition', Modern Languages Open, 1, 2014, 1 <http://doi.org/10.3828/mlo.voi1.39> [accessed 18 February 2020], and Fusso, 'Maidens in Childbirth'.

34 This is changing: besides the studies by Holland and Corrigan cited above, Greta Matzner-Gore devotes a chapter to The Adolescent in Dostoevsky and the Ethics of Narrative Form.

${ }^{35}$ Holland, Novel, pp. 115-23. 
Svidrigailov. There are two rapacious villains; two Versilov sons (our hero, the illegitimate Arkadii, and his legitimate but caddish brother); and two Versilov daughters (the illegitimate Liza, Arkadii's full sister, and his legitimate half-sister, the wily Anna Andreevna). Each Versilov daughter has a different Prince Sokol'skii in prospect as her husband. The two Princes Sokol'skii, old and young, symbolize different generations and world-views. An almost entirely plot-superfluous circle of dangerous freethinkers, briefly and tenuously linked to Arkadii, experiment with the type of terrorist conspiracy which Dostoevskii had already depicted in Demons (the characters Kraft and Vasin are blunter versions of the latter's Kirillov and Shatov).

The Adolescent's plot, or plots, evolve in familiarly seedy St Petersburg settings. There are (narrowly) no murders, but the narrative timeline spans two suicides and one natural death. Arkadii falls in love with a beautiful older woman, Katerina Nikolaevna Akhmakova, after glimpsing her portrait in her father's apartment (echoing the scene where Prince Myshkin first encounters his femme fatale in The Idiot, written six years earlier; this is typical of the novel's tendency to reprise or foreshadow scenes from Dostoevskii's other novels). Arkadii's father Versilov is also obsessed with Katerina Nikolaevna, and his passion for her develops in parallel to his even more inappropriate pursuit of her step-daughter, Lidiia Akhmakova. The latter commits suicide after bearing a child out of wedlock. Meanwhile, Arkadii secretly cherishes a great 'Idea' - a plan to grow wealthy through intelligent miserliness - which recalls other spiteful individualists in Dostoevskii, like the narrator of Zapiski iz podpol'ia (Notes from Underground, 1864) or The Idiot's Gania Ivolgin.

By the end of the novel, Arkadii's 'Idea' and his father-obsession have been suspended, hopefully forsaken, as he agrees to matriculate at university. Many of the younger Dostoevskii's own qualities, as reported by Turgenev and others, re-appear in Arkadii's fictional character: rigorous soul-searching, alternating arrogance and humility, lustfulness and ingenuousness, and the gambling urge. Versilov's bizarre extremes of dissipation and righteousness are clearly intended to represent the contradictions inherent in Russia's decadent aristocracy: Versilov is equally convincing as a scoundrel and as a nobleman (recalling the ambiguous social position of Crime and Punishment's Svidrigailov, who is both nobleman and card sharp). Throughout the novel Versilov regards his son Arkadii primarily as a liability, at best as a pawn to be manipulated. Arkadii hides reluctant adoration behind verbal aggression and naively ignoble schemes to supplant or humiliate his father; even the enigmatic 
Katerina Nikolaevna, desired by both men, is ultimately overshadowed by their love-hate dynamic. Despite this almost intolerable father-son tension, Arkadii attempts to amend or better Versilov's flawed parenting by taking responsibility for surrogate infants of his own, namely a foundling called Arina, as well as Lidiia Akhmakova's orphan child, who may well be Arkadii's half-sibling. The consistent failure of these attempts to re-invent the family reminds us of the death of Stavrogin's and Shatova's child in Demons, a child whose birth deceptively augurs empathy and reconciliation.

In his earliest notes towards The Adolescent, dating from 1874, Dostoevskii had already decided it would be '[a] novel about children, solely about children, and about a boy-hero (N.B. They save a suffering child, stratagems, etc.). They find an abandoned child' ${ }^{36}$ This 'boy-hero' became twenty-year-old Arkadii, The Adolescent's titular protagonist and narrator, and the book famously became the story of the non-traditional and non-nuclear 'accidental family' that takes shape around him. In various 1874 drafts, the hero, a government clerk called Fedor Fedorovich, finds an orphan mysteriously left on his doorstep and decides to adopt him. Next he delays his own wedding in order to devote his life to the child. 'How is it possible not to love children?', he expatiates; in a moment of epiphany provoked by the appearance of the orphan, he forsakes his former socialist beliefs (supposedly inimical to family bonds) for fervent Christianity. ${ }^{37}$ In later versions, the characters of the Adolescent and of Versilov progressively emerge; in every redaction, at least one of them adopts a female child, although the child always dies.

In the final version, published in 1875 , the 'abandoned child' theme has been reduced to a series of subplots within the novel. Arkadii himself identifies as a victim of abandonment by his absent and emotionally manipulative father; indeed, it is hard to find a character in the entire novel who has not been abandoned by Versilov at some point. All the characters, or at least their degree of moral worth, are defined by their treatment of children: one of the earliest warning signs of Versilov's egoism is his lack of interest in his son: as a mere 'screaming baby', Arkadii was not allowed to travel with his mother and Versilov; instead, he was left in the care

${ }^{36}$ Fyodor Dostoevsky, The Notebooks for A Raw Youth, ed. Edward Wasiolek, trans. Victor Terras, Chicago, IL and London, 1969, p. 25; Dostoevskii, Podrostok: rukopisnye redaktsii, PSS, 16, p. 5 .

37 Dostoevsky, Notebooks for A Raw Youth, p. 36; Dostoevskii, Podrostok: rukopisnye redaktsii, PSS, 16, p. 15. 
of others, and later sent to boarding school. ${ }^{38}$ Still later, Versilov briefly abandons both Arkadii's mother and their infant daughter in Königsberg; they are eventually returned to Russia by family friends. The old Prince Sokol'skii, by contrast, one of the novel's most benign characters, talks sentimentally of small children as 'truly God's angels or adorable little birds'. ${ }^{39}$ The welfare of children, whether general or specific, is a constant concern throughout The Adolescent. Yet the original plot of the abandoned child has disappeared from the final, published text. Hence The Adolescent is doubly concerned with the abandonment of babies: on the narrative level, as a recurrent theme; and also narratologically, where the plot has in the course of several drafts abandoned its original focus, the orphaned baby.

Characters or entire plotlines are often reconfigured in important ways in the drafting of Dostoevskii's novels. Crime and Punishment was originally sketched as a first-person narrative; in its earliest versions, the character of Sonia Marmeladova was Siasia, Lizaveta's adult daughter. The title character of The Idiot was initially a 'great sinner' of the ilk of Fedor Pavlovich Karamazov, Stavrogin, or even Versilov; both Joseph Frank and Sarah Young have discussed Prince Myshkin's evolution in Dostoevskii's notebook drafts from a well-networked sinner to a saintly outsider, lacking relatives or connections. ${ }^{40}$ However, The Adolescent's transformation is unusual because the storyline of the abandoned baby, while ceasing to be central to the plot, retains its symbolic importance. Although Arkadii narrates his story at the age of twenty, on the cusp of legal adulthood, he still identifies emotionally as an abandoned child; and he interacts with or attempts to nurture two different orphaned babies, as we will see in the next sections. In addition, Arkadii retells the lives of various babies lost through illness or neglect, including his own younger brother. I suggest that each of these ephemeral infants is a projection of Arkadii's own vulnerability and emotional orphanhood.

Frustrated paternity, the failure of fathers to have children, is an important Dostoevskian theme often expressed through subplots of

${ }^{38}$ Fyodor Dostoevsky, The Adolescent, trans. Dora O’Brien, Richmond, 2016, p. 17; Dostoevskii, Podrostok, PSS, 13, p. 14. I will use this translation throughout, unless otherwise indicated.

${ }^{39}$ Dostoevsky, The Adolescent, p. 35.

40 See Young, The Idiot and the Ethical Foundations of Narrative, p. 115, and Joseph Frank, Dostoevsky: The Miraculous Years, 1865-71, pp. 256-66, for more on the transformation of Prince Myshkin's character. Dostoevskii considered making the Prince illegitimate, which as Frank notes, 'foreshadows a major thematic motif of A Raw Youth [The Adolescent]' (p. 266). 
perinatal mortality, where would-be fathers are frustrated by the loss of their children. Arkadii's special torment, however, is to be frustrated by his own father. Versilov ignores him and neglects his welfare, treating him with an ironic condescension which intensifies Arkadii's resentment. Nor can Arkadii find lasting comfort from his elderly legal father, Makar Dolgorukii, who, like Arkadii's mother, was formerly a serf of Versilov's. Arkadii's mother was a newlywed when Versilov seduced her. Now a wandering pilgrim, Makar tolerates his wife's cohabitation with their former master; their children are legally Makar's, and take his surname. This name becomes a source of social torture for Arkadii, as it happens, ironically, to be the surname of one of Russia's most ancient noble families. Every time Arkadii introduces himself to one of his social peers, inverted snobbery (the absurdity of which he fully realizes) compels him to reject any association with his aristocratic namesakes and, often, to unpack the whole story of his illegitimacy.

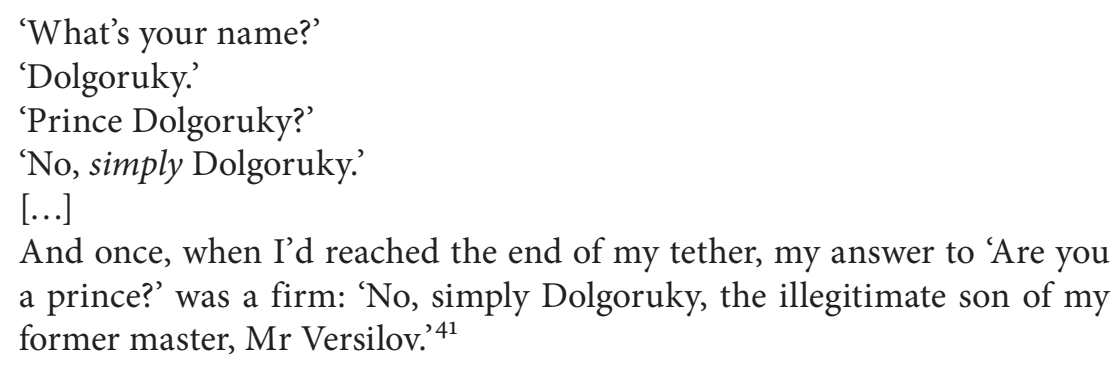

And once, when I'd reached the end of my tether, my answer to 'Are you a prince?' was a firm: 'No, simply Dolgoruky, the illegitimate son of my former master, Mr Versilov. ${ }^{41}$

It is hardly surprising that a hero whose emotional life is dominated by failed or absent father figures should produce a storyline dominated by multiple attempts to do fatherhood properly. As we shall see in the next section, however, the plot itself assimilates and enacts the theme of abandonment, losing the characters and themes it should be following and emphasizing. Like Versilov, the plot is a bad father.

\section{'The Adolescent': Forgetful plots}

The abandonment of babies and children is, as the previous section argued, the central metaphor of The Adolescent. Here I turn to babies - and other characters - who are abandoned, or forgotten, by the plot. Given the circumstances under which Dostoevskii knitted together his complicated novels (poverty, censorship, encroaching emphysema, editorial pressure,

${ }^{41}$ Dostoevsky, The Adolescent, p. 8; Dostoevskii, Podrostok, PSS, 13, p. 8. 
illness and mental agitation, to select a few impediments), he drops astonishingly few narrative stitches. ${ }^{42}$ But most of his novels feature at least one character whose fate is either unresolved, or abruptly dismissed. One example is the abrupt occlusion of a major character in Demons, Liza Tushina, last seen beaten to the ground by rioting townsmen mid-plot; she never re-appears in the narrative. The shocking, unprecedented violence towards Tushina seems to beg further explanation or at least some followup from the narrator. Instead, the reader must infer her death from the narrator's comments and other indirect remarks. ${ }^{43}$ Why is Tushina killed so suddenly and unexpectedly? Should the reader assume that she was pregnant with Stavrogin's child? Another celebrated lacuna occurs in Brothers Karamazov, where the moment of Fedor Karamazov's murder is replaced by an ellipsis in Dmitrii's free indirect narration; the reader is never told, except in Smerdiakov's confession, which of the brothers killed their father. But Smerdiakov is an unreliable narrator, and only Ivan Karamazov hears his confession. The circumstances of Fedor's death are dubious; as Apollonio notes, '[t]he murder itself takes place in the most improbable of temporal intervalss. ${ }^{44}$ Theoretically, therefore, Dmitrii really could have been the murderer. The reader can never definitively conclude whether such narrative gaps are deliberate puzzles set by Dostoevskii, or unintended slips.

Narrative uncertainty is a perpetual problem for The Adolescent's narrator and protagonist, Arkadii Dolgorukii, as he misses social cues and clues, desperately re-evaluates conflicting information, and ingeniously second-guesses his interlocutors. He is particularly exercised by the question of the paternity of the late Lidiia Akhmakova's baby, which is currently Versilov's ward. As with most intimate information about his family's affairs, Arkadii discovers the existence of this baby accidentally: during a humiliating encounter with the scoundrelly moneylender Stebel'kov (who claims to be a 'specialist in midwifery'). ${ }^{45}$ Stebel'kov

${ }^{42}$ For example, on the surprisingly mild impact of grief and gambling losses on Dostoevskii's work on The Idiot, see Frank, The Miraculous Years, pp. 291-93.

43 Fyodor Dostoevsky, Demons, trans. Richard Pevear and Larissa Volokhonsky, London, 1994, p. 539 and p. 552; Dostoevskii, Besy, PSS, 10, pp. 413 and 422.

${ }^{44}$ Apollonio, Reading Against the Grain, p. 162.

45 Stebel'kov, although he calls himself a doctor, presumably refers to 'midwifery' ironically - having in mind the delivery of funds or extra-legal solutions, rather than of babies (The Adolescent, p. 158; Dostoevskii, Podrostok, PSS, 13, p. 121). This pragmatic and ruthlessly scheming character may be a progression of Virginskaia, the nihilist midwife who views the miracle of birth as '[a] nice lot of drivel! [...] simply the further development of the organism, no mystery'. Demons, p. 593; Dostoevskii, Besy, PSS, 10, p. 452. 
informs Arkadii that not only did the latter's father, Versilov, have an affair with Lidiia Akhmakova while simultaneously pursuing her stepmother, Katerina Nikolaevna Akhmakova, Versilov is now raising Lidiia's child Lidiia having poisoned herself post-partum with phosphorous matches.

'A year and a half ago [Versilov] could have achieved a perfect deal over that child - yes, sir, but he went under, yes he did.'

'Over what child?'

'The baby that he's bringing up even now, on the side, but he won't gain anything by it... because...'

'What baby? What's this?'

'His baby, of course, his very own, by Mademoiselle Lidia Akhmakova... "A charming young maiden caressed me." Phosphorous matches - what? ${ }^{46}$

Later in the same day, however, Arkadii learns from his sister Liza that the baby is not Versilov's - and that she should know because she acted as its nanny when it was born. Vasin, a family friend and Liza's would-be husband, also flatly contradicts Stebel'kov's information, although he suggests that Versilov did offer to marry Lidiia Akhmakova to protect her honour after she parted from the baby's real father, the young Prince Sokol'skii. After the baby's premature birth and the death of its mother, Versilov took responsibility for it, paying for an apartment and a nurse in Petersburg (even if the money for this is actually provided by the novel's universal benefactress, a Versilov relative, Tat'iana Pavlovna). The baby's apartment becomes a meeting place for Versilov's adult daughters, Anna Andreevna and Liza, and even on occasion for Arkadii and his father.

An accidental child which is nonetheless cared-for, this unnamed baby reconfigures and potentially resolves the question of the abandoned child from the novel's earliest draft. Despite its peripherality to the main plot - one more confusing secret among the many schemes and suspicions complicating Arkadii's life - this infant's presence sustains both Dostoevskii's original authorial intention and his underlying faith in human goodness. The confusion over its paternity (Versilov and the young prince are both possible fathers) connects two men from opposite sides of the generational divide, who also happen to be Arkadii's two most important mentors in St Petersburg. The baby's home offers a neutral and even nurturing space for Versilov's divided family to meet without conflict.

${ }^{46}$ Dostoevsky, The Adolescent, p. 158; Dostoevskii, Podrostok, PSS, 13, p. 121. Stebel'kov is lewdly quoting Pushkin's poem, 'Chernaia shal'" ('The Black Shawl', 1820), about an unlucky affair with an unfaithful Greek girl. 
The child's illegitimacy recalls the circumstances of Arkadii's own birth, and Versilov's willingness to let his name be associated with it (by offering to marry its mother) reminds us of Makar Dologorukii's complaisance in letting his wife's children keep his name. Moreover, Versilov's actions appear to show a disinterested generosity that is akin to Shatov's unstinting embrace of proxy fatherhood in Demons, when he welcomes back his unfaithful wife and calls her son his own. Whether or not Versilov is the child's father, he seems determined not to abandon this baby, as he previously abandoned Arkadii, Liza and his remaining children, thus resolving the novel's core problem of abandonment. If even Versilov can reform and become a good father, the destructive emotional gap between the generations can be crossed. This orphan embodies an important message of redemption.

And yet, once again, the baby vanishes. In the conclusion of The Adolescent, following the dramatic detonation of the main plotline, Arkadii describes what happened next to all the characters, but omits to mention the fate of the Akhmakova baby. Now that both its mother and its presumed father (the young Prince Sokol'skii) are dead and Versilov has sunk into post-traumatic vacuity, who is taking care of it? Does it still receive someone's charity? Is Katerina Nikolaevna, now free from blackmail, travelling with it? We never find out. The positive symbolism of the adoption, with all that it implied about redemption for fathers, is negated by Dostoevskii's abandonment of this baby. It might have been truer to the original first-draft storyline had Arkadii inherited the baby's care, but as we will see in the next section, Arkadii's adoptions do not go to plan. The omission of the baby's fate from the novel's resolution is just unimportant enough to be a mere oversight - whether accidental (by Arkadii, the narrator) or deliberate (by the implied author). If we assume the latter, as we must (given the ubiquity and significance of babies in the Dostoevskian corpus), this implies narratorial intent behind the baby's disappearance.

The uncertainty or ambiguousness of Dostoevskii's narrators, Vetlovskaia suggests, is in fact as prejudiced ('tendentsioznyi') as their certainty; it leads readers towards certain conclusions. ${ }^{47}$ If we are meant to assume that Arkadii has forgotten the baby, this simple act of forgetting places him in good Dostoevskian company. Diane Oenning Thompson's analysis of forgetting as a theme in Brothers Karamazov finds three major

47 V. E. Vetlovskaia, Roman F. M. Dostoevskogo 'Brat'ia Karamazovy', St Petersburg, 2007, p. 33. 
narrative or symbolic functions of failures of memory. Firstly, forgetting may be a positive act with negative consequences, usually the neglect of children and, consequently, 'the disintegration of the social fabric whose cohesion depends on the shared basis of collective memory. ${ }^{48}$ This is precisely the social disintegration acted out by the fragmented families of The Adolescent. Secondly, forgetting can be deliberate repression, which may lead to loss of control over dangerous memories; and thirdly and most dangerously, it can become 'oblivion [...] the absolute limit of amnesia', the permanent 'obliteration' of memory. ${ }^{49}$

Oblivion is dangerous, according to Thompson, because it signals the total loss of memories, and therefore of family ties; by extension, of moral responsibility and faith in God. While at the time of writing The Adolescent, Dostoevskii had not yet evolved the demonic connotations of amnesia that Brothers Karamazov would showcase (Ivan Karamazov's down-at-heel devil being a case in point), I speculate that the forgotten fate of Lidiia Akhmakova's baby is a foretaste, or a warning, of the moral nihilism that Ivan's devil exemplifies. ${ }^{50}$ We should also note that Arkadii's obsession with paternity (his own, the baby's, and others') is equalled by his implicit obsession with memory: much of his confusion occurs because he is excluded from the social fabric of his family and hence from their collective memory. He collects and collates information about himself, his friends, and his family members not just because of an inchoate sense that knowledge is power (as crudely indicated by his blackmail plans) but in order to re-create shared memories and therefore, by association, shared identity and even a common moral code. The composition of Arkadii's narrative is triggered by 'an inner urge' to 'write down word for word every single thing that's happened to me since last year', despite his explicit contempt for autobiographical literature. ${ }^{51}$ Although by the end of his account, Arkadii appears to have accepted his social position, resolved his familial problems and begun to move forward independently, the mystery of Lidiia's baby signals that the core social ills of fragmentation and forgetting remain current. It is a deliberate narrative omission, steering the reader towards a familiarly inconclusive conclusion that chimes with the Bakhtinian concept of unfinalizability. ${ }^{52}$ As the chaotic narrator and plot of The Adolescent symbolize the social confusion and generational

${ }^{48}$ Thompson, Poetics of Memory, p. 161.

49 Ibid., p. 186.

${ }^{50}$ See ibid., pp. 186-211, for discussion of oblivion as nihilism.

${ }^{51}$ Dostoevsky, The Adolescent, p. 5; Dostoevskii, Podrostok, PSS, 13, p. 5.

52 As Bakhtin warns (in Problems of Dostoevsky's Poetics, trans. Caryl Emerson, London, 2006, p. 166), we should not expect catharsis from Dostoevskian plot. 
slippage of mid-nineteenth-century Russia, so the unresolved fate of this most minor of characters hints at the ambiguity and incompleteness of the ending. Lidiia Akhmakova's forgotten baby - a seed of hope planted in The Adolescent - will grow into other forgotten, neglected, and even parricidal sons in Dostoevskii's next novel, Brothers Karamazov.

\section{Infant death in Dostoevskii's final novels}

We first meet Father Zosima, Alesha Karamazov's mentor and the moral arbiter of Brothers Karamazov, as he consoles a grieving mother for the loss of her three-year-old boy. As he wrote this, Dostoevskii was grieving the loss of his own three-year-old, Alesha. The mother's understated grief ('Only to hear how he walks across the room, just once, just one time, pat-pat-pat with his little feet, so quick, so quick, the way I remember he used to run up to me, shouting and laughing; if only I could hear his little feet pattering and know it was him! But he's gone, dear father, he's gone, and I'll never hear him again!') ${ }^{53}$ is one of the most wrenching passages in the novel. Zosima's response, however, appears both blandly Christian (invoking Rachel, the Biblical archetype of bereaved motherhood) and almost reproachful. Zosima tells the woman: 'your infant, too, surely now stands before the throne of the Lord, rejoicing and being glad, and praying to God for you. Weep, then, but also rejoice. ${ }^{54} \mathrm{He}$ adds, in his own words, 'Why, then, do you trouble his [the dead child's] blessedness? He's alive, surely he's alive, for the soul lives for ever [zhiva dusha voveki], and though he's not at home, he is invisibly near you' ${ }^{55}$ Given that Dostoevskii had experienced bereavement many times, and the loss of a beloved child twice, he would have been familiar with Orthodox texts of spiritual consolation. Should we therefore accept Zosima's consolation literally? Is grief ultimately irrelevant because 'the soul lives forever', and bereavement therefore temporary? Or is there a still more subtle reason to be found to explain the premature deaths of babies and children in Dostoevskii's fiction?

Infant mortality was, of course, tragically commonplace in Dostoevskii's society, and its ubiquity in most of his novels is to some extent mere context. The first dead baby in The Adolescent is the narrator Arkadii's

53 Fyodor Dostoevsky, The Brothers Karamazov, trans. Richard Pevear and Larissa Volokhonsky, New York, 1992, pp. 49-50; Dostoevskii, Brat'ia Karamazovy: Knigi I-X, PSS, 14, p. 46.

54 Dostoevsky, Brothers Karamazov, p. 49; Dostoevskii, Brat'ia Karamazovy: Knigi I-X, PSS, 14, p. 46.

${ }_{55}$ Dostoevsky, Brothers Karamazov, p. 50; Dostoevskii, Brat'ia Karamazovy: Knigi I-X, PSS, 14, p. 47. 
much younger brother, described as 'a sickly little boy [who] was born and died a few months later', apparently echoing the similarly short life of Raskol'nikov's infant brother in Crime and Punishment. ${ }^{56}$ His only purpose in the narrative seems to be to emphasize the final erosion of Arkadii's mother's good looks by 'agonizing childbirth [...] she soon began to age and grow sickly. ${ }^{57}$ On closer reading, however, an apparently deliberate contradiction emerges. Just as pregnancy is a symbol of hope, and birth a symbol of redemption, infant death is apparently the refutation of hope. Yet Dostoevskii's infants tend to die precisely when they should be expected to live: the more hopeful and redemptive the birth, the likelier the death of the child. Should we therefore assume that Dostoevskii's message is the impossibility, for humanity, of reconciliation and moral progress (since even Zosima's consolation offers reconciliation in the afterlife rather than in the present)? Surely this interpretation risks admitting a nihilistic turn, which would oppose Dostoevskii's fundamental beliefs about mutual ethical responsibility.

To solve this apparent contradiction, I examine the stories of infants that die in the course of the narrative, rather than simply vanishing, like the Akhmakova baby previously discussed. The child of Maria Shatova and Stavrogin dies of a cold (probably contracted as an indirect consequence of Shatov's murder) at just a few days old; its truncated life is paralleled by the fates of two 'ghost babies' in the narrative, who are also Stavrogin's children..$^{58}$ The first of these is a purely imaginary baby, the dream-child of the mentally ill Maria Lebiadkina, who fantasizes about bearing Stavrogin's child and drowning it in a forest. The second is Daria Shatova's illegitimate child, whom she miscarries. While the deaths of the latter can be viewed as symbolic confirmation of Stavrogin's emotional and ideological sterility, the death of Maria Shatova's child seems particularly misplaced. Suzanne Fusso argues that the triad of Maria Shatova, her husband and the baby is a deliberate, ekphrastic reconstruction of the Sistine Chapel Madonna on which Dostoevskii placed immense symbolic value. Religious values aside, Shatov's enthusiastic acceptance of another man's child seems to augur a new age of reconciliation and regrowth: "Marie", he cried, holding the baby in his arms, "an end to the old delirium, disgrace, and carrion! Let us work, and on a new path, the three of us, yes, yes!"'59 The

${ }^{56}$ Dostoevsky, The Adolescent, p. 15; Dostoevskii, Podrostok, PSS, 13, p. 13.

57 Dostoevsky, The Adolescent, p. 15; Dostoevskii, Podrostok, PSS, 13, p. 13.

${ }^{58}$ For discussion of these 'ghost babies' and their contribution to Demons' metaphor of sterility, see Maguire, 'Dostoevsky and the Politics of Parturition', pp 7-8.

59 Fyodor Dostoevsky, Demons, p. 594; Dostoevskii, Besy, PSS, 10, p. 453. 
narrative fact that all three are dead within days of this scene seems to suggest that the 'new paths' planned by Dostoevskii's positive characters are as futile as the plans of nihilists and anarchists, like Stavrogin and his radical cohort. The Adolescent seems to confirm this unilateral futility. Arkadii (re-)tells at length two stories which develop Dostoevskii's master theme of frustrated paternity. Both describe attempts to father 'restitutive' children, that is, children who will in some way compensate for the sins of previous generations. In the first story, told originally by Arkadii's legal father Makar Dolgorukii, one of the fathers - members of the older, already corrupted generation - attempts to redeem the wrongs he has committed by fathering a child. In the second story, Arkadii himself (as part of his extended quest to make good his own father's neglect) adopts an abandoned baby. Both are initially hopeful stories, frustrated by the death of the miraculous child.

In the first scenario, Arkadii retells a 'true story' related by his legal father, the former serf Makar Dolgorukii, about a merchant whose hardheartedness successively causes the deaths of a rival and all but one of the latter's five children. Later, apparently because he lacks an heir, the merchant adopts the remaining child, but mistreats him; the terrified child drowns himself. The merchant repents, ultimately persuading his rival's widow to marry him so that they can have a son together to make good the losses of the past. The child is eventually born, welcomed, cherished... only to die eight days after its birth. The merchant, whose brutal character has by now been completely transformed, leaves his home and wife for a prolonged pilgrimage through Russia. Arkadii conveys this talewithin-a-tale without comment, except to suggest that it helps to explain Makar Dolgorukii's own personality and beliefs: certainly, the story is an intriguing study of human self-delusion, and the vanity of attempting to anticipate the ways of God. The merchant, having sinned against little ones and - most shocking of all for Dostoevskii's sensibility - caused a child to commit the mortal sin of suicide, believed that he could redeem their souls and his own by making a new child. ${ }^{60}$ But despite his sincerely good intentions, and despite every resource money could purchase, the innocent infant also perished. Instead of losing his new faith in divine love, the merchant resigns himself, Job-like, to seeking grace without hope of redemption in his lifetime.

${ }^{60}$ Contrast with the excised chapter 'At Tikhon's' in Demons, where a young girl hangs herself after Stavrogin rapes her; a similar, inferred scenario involving Svidrigailov and a teenage girl in Crime and Punishment; or, more subtly, the theme of emotional abuse leading to suicide in the short story, 'Krotkaia' ('A Gentle Creature', 1876). 
The second story, although concerning restitutive adoption rather than conception, is also about frustrated paternity. The teenage Arkadii, while still living in Moscow with his guardians, takes responsibility for an abandoned nursling left on their doorstep. This child is only a few weeks old, and filthy; a note left with the swaddling gives its name as 'Arina' and begs someone to intercede for its welfare. Arkadii's guardian wants to send the child to a foundling home. Acting against his guardian's wishes and, more importantly, against his own cherished Idea, Arkadii uses his own savings and allowance to pay a nurse for the child. The nurse is his building caretaker's wife, a woman who, coincidentally, has just lost her own infant, also Arina, and so recently that her milk has not yet dried up. ${ }^{61}$ Drafts show that Arina the First's father was initially planned as a more important figure, a sort of philosophical mentor to the proto-Arkadii character despite his frequent drunkenness and his cruelty to his wife (whom he eventually burns to death on the stove). ${ }^{62}$ The fact that this wife is still alive to briefly mother both Arinas in the final draft of The Adolescent demonstrates this character's moral upgrade from psychopath to mere alcoholic; but self-interest remains the caretaker's defining characteristic, as he negotiates the foundling's upkeep with Arkadii ('He promptly drank away the money'). ${ }^{63}$ As in Dolgorukii's story of the repentant merchant, a perfect solution appears to have been found: Arkadii is showing charity while compensating for his own neglected childhood, the bereaved mother has a new infant, and Arina the Second has a home. But Dostoevskii rejects perfect solutions. Arina the Second dies of a chest infection after just a few weeks. Very likely (given the level of detail about the child's pulmonary symptoms and the doctor's arrogance) Arina's almost anecdotal tragedy, taking up just three pages of narrative, reflects the circumstances of the death of Dostoevskii's daughter Sonia. ${ }^{64}$

The fates of the two Arinas and of the merchant's redemptive infant are uncompromisingly bleak: they suggest divine intent to frustrate human aspirations, even and perhaps especially when those strivings are towards forgiveness and restitution, turning the reader back upon Father Zosima's bittersweet promise of happiness in the next world. Another canonical literary trope of hopefulness, the symbolic pregnancy, fares no better in

${ }^{61}$ This scenario prefigures the fostering of the infant Smerdiakov, whose birth killed his own mother, by a mother whose infant has just died.

${ }^{62}$ See Fyodor Dostoevsky, The Notebooks for A Raw Youth, pp. 138-41; Dostoevskii, Podrostok: rukopisnye redaktsii, PSS, 16, pp. 94-97.

${ }^{63}$ Dostoevsky, The Adolescent, pp. 103-04; Dostoevskii, Podrostok, PSS, 13, p. 80.

${ }^{64}$ See Dostoevskaia, Vospominaniia, pp. 177-78. 
The Adolescent than in Demons, where both Liza Tushina and Shatov's sister Dasha lose unborn babies. When Arkadii's sister, Liza, becomes pregnant by her lover, the young Prince Sokol'skii (who has already, let us not forget, probably fathered the infamous Akhmakova baby protected by Versilov), the situation is multiply problematic. First of all, Liza's illegitimate pregnancy duplicates her mother's sin with Versilov more than twenty years previously; secondly, although Arkadii is unaware of his sister's situation, no-one realizes how naive he really is. As he blithely lives and carouses with Prince Sokol'skii, even borrowing money from him, the Prince openly despises him as a sponger exploiting his sister's dishonour to extract money from social superiors. Only when the Prince realizes that Arkadii was genuinely ignorant of the whole affair, does he apologize. Liza initially rejects the Prince's offer of marriage because she wants a relationship based on love rather than duty; the Prince, whose commitment to her is at best questionable, dies of fever before they can wed. Vasin (one of The Adolescent's few conventionally moral, but also dull, characters) offers to marry Liza instead and act as father to her child; this recalls the 'other men's sins' subplots in Demons, where Stepan Trofimovich's patron expects him to act as a father for Stavrogin and Daria Shatova's child. But Liza refuses Vasin; and as Arkadii reveals in the novel's conclusion, she miscarries her unborn child after an apparently random accident, leaving her free to continue her life, wiser and sadder. Thus even this secret, complicated seed of hope is lost.

Apollonio notes the dissonance between the metaphorical connotations of pregnancy and childbirth in Dostoevskii and their actual, narrative realizations. Their symbolic message of hope is contradicted by the verbal realization of despair (miscarriage or the death of the newborn). To reconcile both interpretative systems, she suggests an 'apophatic' approach, defined as the study of what is not said, or mis-said, or concealed in Dostoevskii's narratives. For example, in Demons, the real message of the birth of Maria Shatova's child is the joyful and loving image of the Holy Family, rather than the catastrophe of that family's tragic dissolution as the book's real message: 'if we recognize that what we see on the surface of the text is only a disguise, a shed husk, then it no longer blocks access to the truth. [...] In Russian culture, this basic disconnection between the facts and the truth takes the form of an ancient opposition between law and grace. ${ }^{65}$ Perhaps, quite literally, it is the thought that counts: the hope, or act of faith, expressed in the conception and delivery of a child possesses

${ }^{65}$ Apollonio, Reading Against the Grain, pp. 6-7. 
an enduring significance independent of the actual fate of that child. But if we accept Apollonio's apophatic reading, we are left with a second nagging question: if the survival of a newborn baby is immaterial to Dostoevskii's underlying message, why is it so rare? By cutting off every 'new path' represented by infants and adopted children, isn't Dostoevskii guilty of narratorial overkill?

To resolve this question, I suggest a third interpretation, which departs from both Father Zosima's message of resignation and the apophatic interpretation of infants' deaths. When The Adolescent was being written, the ideas of the philosopher Nikolai Fedorov were already well-known in Russian intellectual circles. One of Fedorov's most notorious doctrinal assertions is his promise of universal physical resurrection, that is, the reconstitution of the dissolved bodies of fathers - up to and including our earliest ancestors - by the final generation of humans to be born, the 'sons'. Dostoevskii had already expressed a metaphorical version of this idea of resurrection in a note made following his first wife's death in 1864:

It is said that a person falls apart and dies wholly. We already know therefore that [one does not die] wholly, that a person, by physically creating a son, passes on to him a part of his personality [lichnost'], just as in the moral sense he leaves a memory to his people (N.B. This is acknowledged by the prayer for eternal memory at funeral services). We can see plainly that the memory of those who have advanced humanity lives on among people [...]. This means that a part of these natures enters into other people both spiritually and in a fleshly sense. Christ entered wholly into humanity, and a person tries to transform into the $I$ of Christ as his ideal. ${ }^{66}$

This early passage demonstrates the crucial role of memory in Dostoevskii's philosophy; note Arkadii's struggle to record his own experience as well as those of his family and friends - a process of lexical re-creation of memory and community that succeeds better (since he completes his manuscript) than his attempt to re-create a family by adopting a real child.

In an 1878 letter, Dostoevskii demonstrated both familiarity with and cautious support for Fedorov's radical position on resurrection: here, he queries whether people will be reborn in their 'present bodies' ('v

\footnotetext{
${ }^{66}$ Fedor Dostoevskii, Stat'i i zametki 1862-1865, in Dostoevskii, PSS, 20, p. 174. My translation. For a summary of Dostoevskii's thoughts on Fedorov, see Frank, Dostoevsky: The Mantle of the Prophet, pp. 367-70; for more on Fedorov's influence on Brothers Karamazov, see Robert L. Belknap, The Genesis of The Brothers Karamazov: The Aesthetics, Ideology and Psychology of Making a Text, Evanston, IL, 1990, pp. 78-79.
} 
tepereshnikh telakh'), noting that immortality entails the end of marriage and childbirth. However, he asserts firmly that our ancestors 'will be resurrected not only in our consciousness, not allegorically, but genuinely, individually, actually in bodies' ${ }^{67}$ This extract — with its rejection of resurrection through memory or any other allegorical process - suggests that Dostoevskii's views may have approached Fedorov's in the intervening decade and a half. Whether or not he ultimately accepted Fedorov's extreme position on the resurrection of our ancestors in physical forms, his novels indicate that his moral sympathies had always lain with resurrection (individual and allegorical) rather than rebirth. If the awkward conclusion of Crime and Punishment packages spiritual resurrection as rebirth, this is even more true of The Adolescent's Arkadii, who rises 'reborn but not reformed' (in his own words) after a near-fatal nine days' prostration. ${ }^{68}$ Although Arkadii writes of 'rebirth' ('vozrozhdenie'), he remarks in the same passage that his family have moved him into the sitting room and out of the tiny garret Versilov has nicknamed his 'coffin'. ${ }^{69}$ The parallel with Raskol'nikov's coffin-like lodgings is hard to miss, as is the re-enactment of the Lazarus trope. Even more significantly, Arkadii's rebirth - or resurrection - is lasting, as he exchanges his immature obsessions for maturer goals. We cannot find redemption through others' lives, including the lives of children; but apparently we can still redeem ourselves by reinventing the life we already have. Arkadii's shift in focus from failed would-be fatherhood to successful self-ownership seems to prove this.

We can therefore posit that Dostoevskian babies - whether accidental or not - were doomed not because Dostoevskii lacked faith in human moral progress, but because by the early 1870 s he already believed that the birth of children was a 'new path' in the wrong direction. His least likeable characters (notably Stavrogin, but also Valkovskii and Versilov) are often multiparous and virile, while the heroes and reformed sinners are without issue or lose their children, even and perhaps especially if they are willing to take on 'another man's sin'. Thus the task of the new generation is not reproduction, which risks perpetuating the moral divide between fathers and children. Nor is the solution for sons, as Holquist suggests, to try to become better fathers; we have seen that this effort is all too frequently futile. Fedorov advised sons to resurrect their fathers, firstly in memory and secondly, when the miraculous age of immortality

${ }^{67}$ Fedor Dostoevskii, 'Letter to N. N. Peterson', 24 March 1878, in Dostoevskii, Pis'ma 1878-1881, PSS, 30:1, pp. 13-15 (p. 14). My translation.

${ }^{68}$ Dostoevsky, The Adolescent, p. 379; Dostoevskii, Podrostok, PSS, 13, pp. 283-84.

${ }^{69}$ Dostoevsky, The Adolescent, p. 132; Dostoevskii, Podrostok, PSS, 13, p. 101. 
arrives, in physical bodies. Dostoevskii may have sympathized with this, as the letter cited above suggests. I suggest that Dostoevskii's narratives advised sons to resurrect themselves, allegorically and spiritually, in order to avoid repeating the mistakes of their fathers. The path to redemption and reconciliation leads not into the future, through the mirage of hope presented by childbirth or through Federovian physical resurrection, but in the present, by attempting to lead virtuous lives. This is why Versilov's, Sokol'skii's and Stavrogin's infants die, and why acts of adoption by Versilov, Shatov and Arkadii are doomed to failure. Their deaths are not, however, a nihilistic statement of hopelessness. Rather, they affirm - in the most emphatic way that Dostoevskii knew, through the suffering of children - that responsibility for spiritual change lies with us, and not with our forebears or our posterity.

\section{Conclusion}

Dostoevskii scribbled on an early draft of The Adolescent: 'Most important. The idea of disintegration is present everywhere, for everything is falling apart, and there are no remaining ties not only in the Russian family, but even simply people in general. Even children are apart. ${ }^{70}$ Developing this idea, Holland argues that Dostoevskii 'sought to narrate the processes of social fragmentation that threatened to destabilize institutions such as the family and the nobility, which had been the bedrock of social and political order for centuries. Moreover, he made it his aim to structure disintegration into the novel itself, to represent the process of breakdown on the level of language and literary form. ${ }^{\text {'1 }}$ She has in mind the novel's ranting, disordered, self-contradictory narrative voice and structure, but this wilful formlessness is as characteristic of the plot as it is of the narration. The same might be said of Demons, where the deliberate destabilization of society (although within the frame of a better-organized plot) clearly signals the vulnerability of real-life social infrastructure. In this context, the simplest possible reading of the trope of miscarriage and infant mortality is as yet another indicator of the friability of Russian society.

This reading, however, fails to explain the apparent nihilism of the failure of obviously symbolic attempts (in Demons, by the Shatovs; and by Arkadii and others, in The Adolescent) to re-establish family ties and to

70 Fyodor Dostoevsky, The Notebooks for A Raw Youth, p. 37; Dostoevskii, Podrostok: rukopisnye redaktsii, PSS, 16, p. 16. Italics in the original.

${ }^{71}$ Holland, Novel, p. 21. 
transcend the infamous divide between 'fathers' and 'sons'. As successive tales of miscarriage and infant death demonstrate, Dostoevskii changed the reassuring literary trope of birth as renewal, to a new symbolism of birth as disaster. Births in Dostoevskii's fiction break from the family novel tradition by no longer signalling happy endings: if the birth is even brought to term and if the baby is even remembered in the plot (neither of which can be taken for granted, as we have seen), the next event is, all too often, the infant's death. Nor is this a sentimental Dickensian expiry, intended to arouse readers' sympathy for a neglected child: most of these infant deaths occur in brief or tangential sub-plots. Rather than happy endings, these births are simply endings: for hopes, for innocence, for the infant and often for the parents, too. This bleak interpretation would be at odds with Dostoevskii's profound faith in Christ and his reverence for the image of the Christ-child: despair is, after all, a mortal sin. I have argued that Dostoevskii's fictional children die because the problem of children's suffering and death was so central to Dostoevskii's faith, and so emotive for him and for his readers. Dostoevskii was critiquing Russian society, but he was also critiquing humanity as a whole; and in particular, our reliance on marriage and childbirth — on re-producing ourselves - as a solution to moral and social ills. True birth must be re-birth, reinvention of the self and of wider society from within; and such resurrection begins with personal spiritual reform - a potential that the characters of Alesha and Dmitrii Karamazov glimpse at the end of Brothers Karamazov, and which they might have been allowed to fulfil in that novel's unwritten sequel. 